Environmental Pollution

September 2017, Volume 228 Pages 454-463

http://dx.doi.org/10.1016/i.envpol.2017.05.047

http://archimer.ifremer.fr/doc/00389/50016/

(C) 2017 Elsevier Ltd. All rights reserved

\title{
Interactions between polystyrene microplastics and marine phytoplankton lead to species-specific hetero-aggregation
}

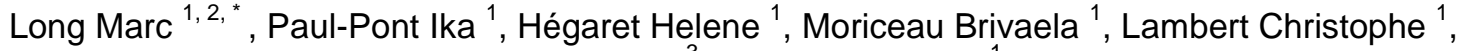 \\ Huvet Arnaud ${ }^{3}$, Soudant Philippe ${ }^{1}$
}

${ }^{1}$ Laboratoire des Sciences de l'Environnement Marin (LEMAR), UMR 6539 CNRS UBO IRD IFREMER

- Institut Universitaire Européen de la Mer, Technopôle Brest-Iroise, Rue Dumont d'Urville, 29280

Plouzané, France

${ }^{2}$ School of Chemistry, University of Wollongong, NSW 2522, Australia

*Corresponding author : Marc Long, email address : marc.florian.long@gmail.com

\begin{abstract}
:
To understand the fate and impacts of microplastics (MP) in the marine ecosystems, it is essential to investigate their interactions with phytoplankton as these may affect MP bioavailability to marine organisms as well as their fate in the water column. However, the behaviour of MP with marine phytoplanktonic cells remains little studied and thus unpredictable. The present study assessed the potential for phytoplankton cells to form hetero-aggregates with small micro-polystyrene (micro-PS) particles depending on microalgal species and physiological status. A prymnesiophycea, Tisochrysis lutea, a dinoflagellate, Heterocapsa triquetra, and a diatom, Chaetoceros neogracile, were exposed to micro-PS $(2 \mu \mathrm{m}$ diameter; $3.96 \mu \mathrm{g} \mathrm{L}-1)$ during their growth culture cycles. Micro-PS were quantified using an innovative flow-cytometry approach, which allowed the monitoring of the micro-PS repartition in microalgal cultures and the distinction between free suspended micro-PS and hetero-aggregates of micro-PS and microalgae. Hetero-aggregation was observed for $\mathrm{C}$. neogracile during the stationary growth phase. The highest levels of micro-PS were "lost" from solution, sticking to flasks, with T. lutea and $\mathrm{H}$. triquetra cultures. This loss of micro-PS sticking to the flask walls increased with the age of the culture for both species. No effects of micro-PS were observed on microalgal physiology in terms of growth and chlorophyll fluorescence. Overall, these results highlight the potential for single phytoplankton cells and residual organic matter to interact with microplastics, and thus potentially influence their distribution and bioavailability in experimental systems and the water column.
\end{abstract}




\section{Graphical abstrac}

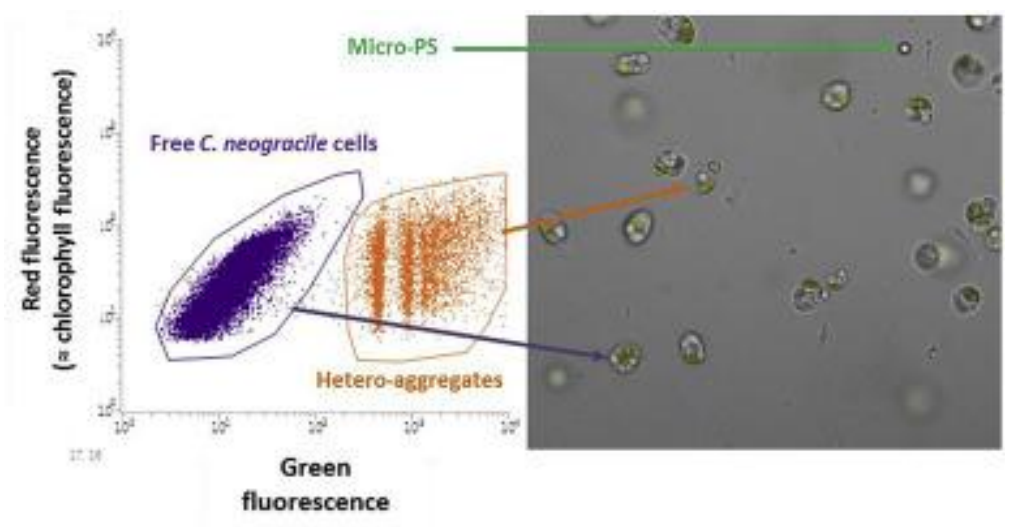

\section{Highlights}

Chaetoceros neogracile formed hetero-aggregates with micro-polystyrene. Hetero-aggregation of C. neogracile increased with culture age. Micro-polystyrene did not affect growth, morphology or fluorescence of free algal cells. Microplastic distribution and bioavailability may differ among species and experimental systems. Flow cytometry and 3D microscopy are good tools for studying MP distribution in water.

Keywords : Polystyrene, Microplastic, Aggregates, Microalgae, Marine, Phytoplankton 


\section{Introduction}

Microplastics (MP), defined as plastic particles below $5 \mathrm{~mm}$ diameter (Arthur et al., 2009), constitute an emerging threat in marine ecosystems due to the overall quantity of plastic debris entering the oceans every year. Indeed, Jambeck et al. (2015) estimated that 4.8 to 12.7 million metric tons of plastic waste entered the world's oceans in 2010, with a steady increase expected in the following years. In addition, the ubiquitous nature of these microparticles has been shown to lead to their accumulation in oceans over the last decades (Eriksen et al., 2014; Woodall et al., 2014). According to Van Sebille et al. (2015), up to $51.2 \times 10^{12} \mathrm{MP}$ particles are presently floating in marine environments worldwide.

Ingestion of MP by marine organisms, via direct uptake of free MP (Cole et al., 2011; Rochman et al., 2016; Sussarellu et al., 2016) or through consumption of contaminated preys (Farrell and Nelson, 2013), has been demonstrated in laboratory studies. Numerous field studies have also shown the presence of MP in fishes (Boerger et al., 2010; Lusher et al., 2013; Rummel et al., 2016; Sanchez et al., 2014), crustaceans (Murray and Cowie, 2011) and a wide range of filter feeders including bivalves (Van Cauwenberghe and Janssen, 2014), polychaetes (Van Cauwenberghe et al., 2015) and whales (Besseling et al., 2015). Such findings are of great concern, as physical and toxicological impacts have been observed both in cases of MP ingestion (for review see Rochman et al. (2016); Wright et al. (2013); for recent studies see Green (2016); Jemec et al. (2016); Paul-Pont et al. (2016); Sussarellu et al. (2016)) and food chain transfer arising from predator/prey interactions (Farrell and Nelson, 2013; Setälä et al., 2014). Nevertheless, it is still not clear how MP enter the marine food web. While free MP can be taken up directly by organisms (e.g. from mussels to crabs (Farrell and Nelson, 2013) or from beach hoppers to ray-finned fish (Tosetto et al., 2017)), they could also be ingested via vectors. For instance, (Ward and Kach, 2009) experimentally demonstrated a facilitated transfer of nanoplastics (NP) to filter feeders through marine aggregates.

In the marine environment, MP can drift alone in the water column, but are also likely to interact with the surrounding marine plankton (Cole et al., 2016, 2013; Lagarde et al., 2016; Long et al., 2015; Setälä et al., 2014). For instance MP and NP can be efficiently incorporated in marine phytoplankton aggregates, which modify MP settlement rates in the water column (Long et al., 2015) and favour ingestion of NP by suspension-feeding bivalves (Ward and Kach, 2009). However, the behaviour of MP with phytoplanktonic aggregates and single cells has been little studied. The interactions of MP with phytoplankton have only been reported at very high concentrations, ranging from $25 \mathrm{mg}$ to $2 \mathrm{~g}$ $\mathrm{L}^{-1}$. Studies on freshwater microalgae demonstrated significant interactions and rapid formation of hetero-aggregates when microalgae were exposed to $20 \mathrm{~nm}$ nano-polystyrene at $80-800 \mathrm{mg} \mathrm{L}^{-1}$ (Bhattacharya et al., 2010) and 400-1000 $\mu \mathrm{m}$ MP (polypropylene and high-density polyethylene) at 1 
$\mathrm{g} \mathrm{L}^{-1}$ (Lagarde et al., 2016). The only report of aggregation with a marine species was observed between the diatom Skeletonema costatum and micro-polyvinyl chloride (micro-PVC at 50-2000 mg $\mathrm{L}^{-1}$ ) (Zhang et al., 2017). Significant impact on growth rate was reported for the marine flagellate Dunaliella tertiolecta exposed to $250 \mathrm{mg} \mathrm{L}^{-1}$ of $0.05 \mu \mathrm{m}$ micro-polystyrene (micro-PS) (Sjollema et al., 2016), but no hetero-aggregation was observed.

From recent literature (Maes et al., 2017; Sgier et al., 2016; Shim et al., 2016), tools based on fluorescence analysis, such as Flow cytometry (FCM), appear to be a relevant approach for rapid and robust detection and analysis of microplastics. FCM is a routine method that allows the analysis of various particle types within a flux. This technique enables the quantification and the characterization of particle parameters through measurements of light scattering and fluorescence (natural or following staining) after excitation by a laser beam. FCM has already been widely used for the study of microorganisms, including marine phytoplankton (Estrada et al., 2004; Lelong et al., 2011b; Pomati et al., 2011). FCM has the advantage of quickly and simultaneously analysing several parameters on large quantities of suspended cells. Moreover, FCM can be combined with several extensions such as camera or cell sorter, which allows the detection of microplastics (Sgier et al., 2016).

The aim of the present study is to investigate the potential for marine phytoplankton cells to aggregate with micro-PS depending on phytoplankton species and physiological state under experimental conditions. The present study focused on small MP $(2-\mu \mathrm{m}$ yellow-green fluorescent polystyrene microspheres; micro-PS). Polystyrene is one of the three most commonly used plastic polymers worldwide (alongside polyethylene and polypropylene), and is frequently found among microplastics sampled at sea (Barnes et al., 2009; Browne et al., 2010; Hidalgo-ruz et al., 2012). Three different marine phytoplankton species from different taxonomic groups were tested. The species were selected based on their predominance in marine phytoplankton communities and because of their common inclusion in bivalve diets (Dalsgaard et al., 2003; Malviya et al., 2016; Robert et al., 2004). The diatom Chaetoceros neogracile is a non-motile cell (width $=4 \mu \mathrm{m}$, length $=7 \mu \mathrm{m}$ ) encased in siliceous valves known as frustules covered with an organic coating (Hecky et al., 1973). The prymnesiophyceae Tisochrysis lutea is a small motile cell (width $=5 \mu \mathrm{m}$, length $=6 \mu \mathrm{m}$ ) covered by a dense layer of thin organic scales (Bendif et al., 2013). The dinoflagellate Heterocapsa triquetra is a motile cell (diameter $=16 \mu \mathrm{m}$, length $=23 \mu \mathrm{m}$ ) encased in a theca covered by an external plasmic membrane (Dodge and Crawford, 1970). The partitioning (aggregation and attachment to algae) of micro-PS was evaluated over an entire culture cycle, from seeding to stationary growth phase for each algal species. The potential toxic effects of MP on microalgal physiology was investigated through the analysis of growth rates and chlorophyll auto-fluorescence, which can be used as a proxy 
of photosynthetic efficiency (Lelong et al., 2011a). All analyses (cell and particle counts, formation of hetero-aggregates, algal viability and photosynthetic activity) were performed by flow cytometry.

\section{Materials and methods}

\section{Algal culture}

Two species of algae, Chaetoceros neogracile $(5.3 \mu \mathrm{m})$ and Tisochrysis lutea $(4.5 \mu \mathrm{m})$ were obtained from the Scottish Marine Institute. The dinoflagellate Heterocapsa triquetra $(18 \mu \mathrm{m})$ (strain HT99PZ Ehrenberg, 1840) was isolated in the Penzé river (bay of Morlaix, France). Non-axenic cultures were grown in autoclaved F/2 medium (Guillard, 1975) made with filtered $(0.22 \mu \mathrm{m})$ natural seawater. F/2 medium was enriched with silica $\left(1.0710^{-4} \mathrm{M}\right)$ for the diatom $C$. neogracile. Cultures were performed in $250 \mathrm{~mL}$ glassware balloon flasks filled with $100 \mathrm{~mL}$ of medium maintained at $16^{\circ} \mathrm{C}$ under a $12 / 12$ hour photoperiod with $92 \pm 13 \mu \mathrm{mol}$ photons $\mathrm{m}^{-2} \mathrm{~s}^{-1}$.

\section{Microplastic exposure}

Pristine 2- $\mu \mathrm{m}$ polystyrene beads (micro-PS) (yellow-green fluorescent, density of $1.05 \mathrm{~g} \mathrm{~mL}^{-1}$, smooth and uncharged, solution in deionised water containing $0.1 \%$ Tween 20 ) obtained from Polysciences Inc. were used in this experiment. Exposures were performed in glass flasks to minimize losses caused by plastic attraction to the flask walls. Micro-PS were added to the medium at the beginning of the experiment just after microalgal inoculation (9 $10^{5}$ micro-PS $\mathrm{mL}^{-1}$, corresponding to $3.96 \mu \mathrm{g} \mathrm{\textrm {L } ^ { - }}$ $\left.{ }^{1}\right)$. It is noteworthy that the same experiment was also performed using a concentration of micro-PS ten times higher (9 $10^{6}$ micro-PS $\mathrm{mL}^{-1}$, corresponding to $39.6 \mu \mathrm{g} \mathrm{L}^{-1}$ ) than the concentration presented here. Data from this second experiment are not discussed in the paper as they give identical results, but they are available in supplementary tables 1 to 7. A good dispersion of the micro-PS in the culture media was confirmed in a preliminary experiment. Two sets of controls were set up: non-exposed microalgae cultured without addition of micro-PS, and micro-PS maintained in clean F/2 medium without any algae. Cultures and control flasks were set up in triplicate and were sampled 6 to 8 times from early exponential phase to stationary growth phase for flow cytometric and microscopic analyses. Micro-PS and microalgae were kept in suspension and homogenized by gently stirring the flasks every day and prior to sampling. Micro-PS detection and count were performed on fresh samples, while algal cell concentrations and chlorophyll fluorescence intensity were measured on fixed samples (glutaraldehyde, $0.3 \%$ final concentration), frozen in liquid nitrogen and stored at $-80^{\circ} \mathrm{C}$. Growth rates $\left(\mathrm{day}^{-1}\right)$ were estimated according to the following equation: 
$\mu=\frac{\operatorname{Ln}\left(C_{2} / C_{1}\right)}{T_{2}-T_{1}}$

$\mathrm{C}_{1}$ and $\mathrm{C}_{2}$ being the cell concentrations (cell $\mathrm{mL}^{-1}$ ) at $\mathrm{T}_{1}$ and $\mathrm{T}_{2}$ (days) corresponding to the beginning and the end of the exponential growth phase, respectively.

\section{Flow cytometry (FCM)}

Microalgal cells and micro-PS were counted using a FACSCalibur flow cytometer (Becton Dickinson, San Diego, CA, USA) equipped with a blue laser (excitation $488 \mathrm{~nm}$ ). All particles analysed by FCM were characterized according to their forward scatter (FSC), side scatter (SSC) and red (FL3; red emission filter long pass, $670 \mathrm{~nm}$ ) or green fluorescence intensity (FL1; green emission filter band pass, $530 / 30 \mathrm{~nm}$ ). Microalgal populations were identified according to their high level of FSC, high level of FL3, which is related to chlorophyll autofluorescence (Galbraith et al., 1988; Hariskos et al., 2015; Sosik et al., 1989) and low level of FL1 (Figures 1A and 1G).

Micro-PS and micro-PS homo-aggregates were identified by their lower levels of FSC and FL3 and their high levels of FL1 related to their green fluorescence (Figures 1D and 1E). Hetero-aggregates were identified by their high levels of FSC, FL3 and FL1 (Figures $1 \mathrm{G}$ and $1 \mathrm{H}$ ). Neither algal debris nor micro-PS homo-aggregates disturbed the FCM analysis as they exhibited different features in the FCM measurements: lower levels of FSC, SSC and FL3 for microalgal debris and higher level of FL1 but still low level of FL3 for micro-PS homo-aggregates.

Data were analysed using Cellquest software and concentrations of microalgal cells or micro-PS were calculated (cell $\mathrm{mL}^{-1}$ ) from the number of events per unit time and the estimate of the FacsCalibur flow rate measured according to Marie et al. (1999). By measuring the FL1 fluorescence intensity it was possible to determine single micro-PS and groups of 2, 3 or more micro-PS, either in heteroaggregates (Figure 1I) or in micro-PS homo-aggregates. Concentrations of micro-PS were thus corrected according to the number of beads in micro-PS aggregates.

Micro-PS partitioning in the glass flasks was defined as (i) free suspended beads, (ii) heteroaggregates constituted by micro-PS and microalgal cells and (iii) microbeads adsorbed to the glassware (on the flask walls). The amount of adsorbed beads was estimated by subtracting the number of micro-PS present in the media (as free suspended beads, micro-PS homo-aggregates or hetero-aggregates) at the time of sampling from the number of micro-PS present in the glass flasks (measured at the start of the incubation). 


\section{D Fluorescent Microscopy}

As it was impossible to tell by flow cytometry whether the beads were present inside or outside the microalgal cells, microscope observations were performed to confirm the adhesion and/or engulfment of the micro-PS to/by algae. Both the attachment of micro-PS to algal cells and phagotrophic events were observed using a Zeiss Axio Observer Z1 inverted fluorescence microscope coupled to a 3D Vivatome unit. Fluorescent micro-PS could be viewed using GFP filters (Excitation 494/20 nm, Emission 536/40 nm) and chloroplasts were visible using DsRed filters (Excitation 575/25 $\mathrm{nm}$, Emission 628/40 nm). Z-stack was used to visualize internal beads with Axovision Rel. 4.8 software.

\section{Statistics}

Statistical analyses of growth rates and physiological parameters (FI3 auto-fluorescence, FSC and SSC) were performed using R software (R Foundation for Statistical Computing, Vienna, 2011) with a level of statistical significance at $p$-value $<0.05$. Differences in growth rate and chlorophyll fluorescence intensity among the different experimental conditions were assessed with non-parametric KruskalWallis tests. Results are expressed as mean value \pm standard error (SE).

\section{Results}

\section{Micro-PS distribution in the cultures}

In the control flasks containing only micro-PS, the micro-PS concentration suspended in the water decreased over time (Figure 2A) as the micro-PS adsorbed to the glassware. The percentage of suspended micro-PS was $91 \pm 4 \%$ (mean \pm SE) after $24 \mathrm{~h}$, and then progressively decreased down to $47 \pm 7 \%$ at day 28 and increased back to $66 \pm 5 \%$ at day 35 . Within the suspended micro-PS fraction, it is worth noting that the amounts of micro-PS homo-aggregates increased over time in both the control and the exposed treatment flasks. Bacterial aggregates (Figure $3 \mathrm{~A}$ ) were detected by microscopic observations in all the flasks, including the control flask, with some micro-PS trapped within these aggregates (Figure 3B).

In C. neogracile flasks, $81 \pm 3 \%$ of the micro-PS were in suspension and no hetero-aggregates were formed at day 1 (Figure 2B). By the mid-exponential growth phase (day 13), the percentage of suspended micro-PS increased to $96 \pm 1 \%$ (Figure $2 \mathrm{~B}$ ), these were free and neither bound to nor inside the diatoms. At the end of the exponential phase (day 20), micro-PS were predominantly free in suspension $(83 \pm 3 \%$ ), and in low proportions in the form of hetero-aggregates $(2 \pm 1 \%)$ (Figures 
$1 \mathrm{H}, 1 \mathrm{I}$ and $3 \mathrm{C}$ ) and adsorbed to the glassware (14 $\pm 3 \%$ ) (Figure $2 \mathrm{~B}$ ). Finally, in stationary growth phase (day 29), the proportion of hetero-aggregates consisting of diatoms and micro-PS reached $19 \pm$ $6 \%$.

In T. lutea flasks (Figure 2C), no data is available for days 1 and 2 due to sampling issues. On day 3, no hetero-aggregates were observed and $79 \pm 4 \%$ of the micro-PS appeared in suspension as free beads or homo-aggregates. The fraction of micro-PS stuck to the glassware increased throughout the growth cycle up to $75 \pm 4 \%$ at the end of the exponential growth phase (day 14), while $22 \pm 4 \%$ of the remaining micro-PS were suspended and only $3 \pm 1 \%$ were detected as hetero-aggregates. During the stationary growth phase, no hetero-aggregates were observed, most micro-PS were adsorbed to the glassware (97 $\pm 1 \%$ ), while the remaining $3 \pm 1 \%$ were in suspension.

In H. triquetra cultures (Fig. 2D), $22 \pm 2 \%$ of the micro-PS were adsorbed to the glassware and $78 \pm$ $2 \%$ remained free in suspension at day 1 . The proportion of micro-PS free in suspension decreased steadily over time reaching $15 \pm 2 \%$ in the stationary growth phase (day 24 ). Although they could not be adequately quantified by FCM throughout the growth cycle, occasional cases of phagotrophy of micro-PS (Figure 3D), aggregation of micro-PS within cell lysis products (Figure 3E), and heteroaggregation (Figure 3F) were observed through microscopic observations on $\mathrm{H}$. triquetra.

\section{Impact of micro-PS on microalgal physiology}

No significant effect of micro-PS exposure was detected on the growth rate of any of the three species at any time during the experiment. $C$. neogracile, $H$. triquetra and $T$. lutea reached the stationary growth phase after 22, 23 and 15 days, respectively. Mean growth rates were higher for $T$. lutea with $0.450 \pm 0.004$ days $^{-1}$ (mean $\pm \mathrm{SE}$ ) in controls and $0.440 \pm 0.005$ days $^{-1}$ for the micro-PS treatment. Mean growth rate of $C$. neogracile was $0.227 \pm 0.004$ days $^{-1}$ for the control and $0.227 \pm$ 0.011 days $^{-1}$ when exposed to micro-PS. H. triquetra had the lowest growth rate, with $0.206 \pm 0.006$ days $^{-1}$ in the control and $0.198 \pm 0.005$ days $^{-1}$ with micro-PS.

No differences were observed in microalgal chlorophyll content (as estimated by autofluorescence intensity detected on the FL3 detector of the flow-cytometer), forward scatter or side scatter between controls and micro-PS exposed cultures for the three tested species (Tables 1, 2 and 3).

\section{Discussion}

Hetero-aggregation with micro-PS is dependent on species and culture physiological stage 
Hetero-aggregation between MP and $C$. neogracile is in agreement with field observations that showed plastic particles associated with diatoms, including the pelagic genus Chaetoceros (Reisser et al., 2014; Zettler et al., 2013). Our results tend to show that exposures of $C$. neogracile to micro-PS resulted in hetero-aggregation when cells reach the stationary growth phase. The release by phytoplankton of extracellular polysaccharides (EPS) with sticky properties is common for phytoplankton species and can induce aggregation. The genus Chaetoceros is particularly known to produce high amount of TEP (Transparent exopolymeric particles) resulting from EPS aggregation (Kiørboe and Hansen, 1993; Li et al., 2016; Passow et al., 1994). Moreover, EPS excretion with increasing stickiness is often associated with nutrient depletion, which occurs at the end of culture (Joiris et al., 1982; Kiørboe et al., 1990; Logan and Alldredge, 1989). Since EPS/TEP production was not measured here, further studies are needed to confirm the hypothesis linking cell physiology, EPS and the formation of hetero-aggregates with micro-PS.

In the current study, neither the micro-PS stock solution nor the algal cultures were axenic. Bacteria associated with the micro-PS stock solution or algal cultures had likely grown in experimental cultures and controls. Bacteria can also produce exopolysaccharides with sticky properties (Bhaskar et al., 2005; Passow, 2002b). Moreover, bacteria and algae can be associated to produce EPS, TEPs, and promote aggregation (Alldredge et al., 1993; Passow, 2002a,b). Thus it is reasonable to assume that bacterial exudates or debris may also have participated in the homo- and hetero-aggregation of micro-PS and/or their adsorption to glassware. In addition to bacterial and algal exudate, lysis of algal cells during the growth cycle may have released some partially dissolved organic molecules that possibly acted as glue. This was observed in the $H$. triquetra cultures, where micro-PS seemed to be trapped in the lysis products of dying cells. This suggests that the decrease in free suspended microPS, even after re-suspension by stirring, is associated with some organic binding of micro-PS to the glassware.

Phagotrophy describes the process by which unicellular organisms derive their food by engulfing and digesting other cells. As far as we know, this is the first report of MP phagotrophy by phytoplankton, even though phagotrophy of micro-PS was only rarely observed in this experiment. The dinoflagellate H. triquetra is a mixotrophic algal species able to phagocytose bacteria and small algae (Legrand et al., 1998). Such observations indicate that mixotrophy could be another pathway for MPs to enter the food web and is therefore a subject that deserves to be studied further.

\section{Micro-PS exposure had no effect on algal physiology}

Micro-PS did not affect algal growth or the physiological parameters measured by flow cytometry under our experimental conditions $\left(3.96 \mu \mathrm{g} \mathrm{L}^{-1}\right.$; for the higher concentration of $39.6 \mu \mathrm{g} \mathrm{L}^{-1}$ see results 
in supplementary tables 4 to 7). This is in agreement with previous studies that explored the effect of $\mathrm{MP}$, tested at similar or higher concentrations, on the health of different microalgal species (Davarpanah and Guilhermino, 2015; Lagarde et al., 2016; Sjollema et al., 2016). Due to confounding factors of MP dose and size in laboratory experiments, conflicting results on MP toxicity exist in the literature. Zhang et al. (2017) found a negative impact of micro-PVC (average $1 \mu \mathrm{m}$ ) on Skeletonema costatum growth and chlorophyll fluorescence at high concentration $\left(50 \mathrm{mg} \mathrm{L}^{-1}\right)$. They hypothesized that blockage of alveoles and cell surface physical damage were responsible for the decrease in microalgal growth. Similarly, Sjollema et al. (2016) highlighted an impact of micro-PS on the growth rate but not on photosynthetic efficiency for the marine flagellate Dunaliella tertiolecta, but only at very high exposure concentrations $\left(250 \mathrm{mg} \mathrm{L}^{-1}\right)$ with small particle size $(0.05 \mu \mathrm{m})$. For larger microplastics $(>400 \mu \mathrm{m})$ of different polymer type (polypropylene and high density polyethylene), no deleterious effects were observed on the freshwater microalgae Chlamydomas reinhardtii, even at high concentration ( $1 \mathrm{~g} \mathrm{~L}^{-1}$ ) (Lagarde et al., 2016). However, growth and photosynthesis appeared affected in the freshwater algae Scenedesmus sp. at $1 \mathrm{~g} \mathrm{~L}^{-1}$ (Besseling et al., 2014) and Chlorella sp. at $1.8 \mathrm{mg} \mathrm{L}^{-1}$ (Bhattacharya et al., 2010) exposed to polystyrene nanoparticles (< $70 \mathrm{~nm}$ ). Indeed, particle size may be a crucial parameter for toxicity. Nanoplastics may be more likely than MP to interact with algal cell membranes by, for instance, inducing shading, or blocking microalgal pores or gas exchanges (Bhattacharya et al., 2010). In addition, a molecular simulation study by Rossi and Monticelli (2014) predicted that PS nanoparticles could permeate lipid membranes. This would severely affect the activity of membrane proteins and enhance absorption of NP compared to MP.

\section{Bioavailability and distribution of microplastics must be measured in laboratory experiments}

Our results demonstrated that MP behaviour under the conditions of this experimental study, here using phytoplankton cultures, cannot be predicted and requires rigorous measurement. It was clearly shown that micro-PS may adsorb to glassware, form homo-aggregates and hetero-aggregates with phytoplankton cells, residual organic matter and/or bacteria exudates. These results underline the need to quantify the bioavailability and distribution of MPs in the experimental systems. Furthermore, MP distribution in different media (e.g. suspended, floating, adsorbed to experimental containers, trapped in organic aggregates, or adsorbed on or ingested by organisms) must be assessed to obtain accurate values of the actual MP concentration to which the organisms are exposed, as it is commonly done for other pollutant studies. For instance, in Sussarellu et al. (2016), a supplementary tank without animals was set up for each treatment to evaluate micro-PS sinking or sticking to the plastic (polymethylmetacrylate, commonly known as Plexiglas) tank walls. Estimation of exposure concentration in the water surrounding the animals was half the nominal mass concentration. This also applies to other polymer types, especially polyethylene, which has a lower 
density than seawater and positive buoyancy, which may prevent homogeneous exposure. During laboratory experiments, the particles may remain at the water surface, i.e. unavailable to marine organisms such as filter feeders (Von Moos et al., 2012). To avoid this, Green (2016) reduced the buoyancy of neutral MP (high density polyethylene and polylactic acid) by mixing them with cultures of Isochrysis galbana 3 days prior to exposure. This made them bioavailable to flat oysters Ostrea edulis. Overall, the variety of MP occurring in the environment is more diverse (polymer size, type, shape and concentration) than the spherical MP commonly used in laboratory experiments and this should be adequately addressed in future studies (Huvet et al., 2016). Considered together, these findings show that experiments should be designed carefully, specifically for MP, in order to avoid difficulties/artefacts caused by the intrinsic properties of these particles.

\section{Future directions for field studies}

Observations of micro-PS adsorbing to suspended cells of $C$. neogracile and bacterial aggregates suggests that suspended particulate organic matter may influence MP buoyancy and settling in the water column (and vice versa), as already suggested for phytoplankton aggregates (Long et al., 2015) and zooplankton faecal pellets (Cole et al., 2016). If hetero-aggregation occurs in marine environments (yet to be proven), this may contribute to the incorporation of MP in phytoplankton aggregates (marine snow) as it is forming, in addition to their direct incorporation in phytoplankton aggregates once these are already formed and settling to the bottom (Long et al., 2015). This is of particular concern as aggregation was shown to enhance ingestion of $0.1 \mu \mathrm{m}$ nano-PS by bivalves (Ward and Kach, 2009). Altogether these results support the hypothesis that the phytoplankton compartment is a potential sink and vector for MP trophic transfer in marine food webs.

Although this study has highlighted a mechanism, the ecological relevance of such laboratory observations is likely low, as they are far from reflecting the complexity of the marine environment (relatively static conditions, small volumes, high algal cell concentrations, one microalgal species, one plastic type, size, dose, etc.). For instance, hetero-aggregation appears dependent on both plastic composition (Lagarde et al., 2016) and microalgal species, it is thus likely to vary with changes in phytoplankton communities. Further studies moving towards more realistic scenarios (e.g. natural plankton communities or mesocosm experiments) are required to evaluate the ecological relevance of phytoplankton/MP hetero-aggregation. To make this possible, technological developments are required to improve MP sampling at sea, especially the fraction consisting of small MP, which may be associated with suspended organic and inorganic materials. For instance, sediment traps should be used at sea to collect marine snow and faecal pellets, potentially containing associated MP. Relevant concentrations experiments should also be favoured (Lenz et al., 2016), however this requires urgent 
methodological development for quantifying the smallest microplastics $(<50 \mu \mathrm{m})$ in marine ecosystems (Huvet et al., 2016). For instance, the mass concentration of $3.96 \mu \mathrm{g} \mathrm{L}^{-1}$ used in the present study was lower than microplastic concentrations measured in various ecosystems (see Supplementary Table 1 in Sussarellu et al. (2016)) even though strict comparison between $>330 \mu m$ and $2 \mu \mathrm{m}$ fraction are hard to make.

\section{Flow cytometry and 3D microscopy are useful tools for investigating MP distribution in water}

Flow cytometry enabled us to investigate the distribution of fluorescent micro-PS within the phytoplankton cultures, quantifying the proportion and the state of micro-PS in suspension as free beads, homo-aggregates and hetero-aggregates made of micro-PS and microalgae. The quantification limit of the flow cytometer used in the present study (FACSCalibur FCM) allowed the measurement of micro-PS even at low concentrations, i.e. down to 500 micro-PS $\mathrm{mL}^{-1}$ (meaning a mass of $2 \mathrm{ng} \mathrm{L}^{-1}$ ) for an analysis of 1 minute. It is noteworthy that this quantification threshold could also be decreased by increasing either flow rate or processing time. While flow cytometry could provide a fast and quantitative method to analyse micro-PS concentration and distribution, we consider that visual confirmations are required to ensure a proper interpretation of cytograms. In our case, use of 3D microscopy allowed micro-PS adsorbed to the cell surface to be distinguished from those phagocytized by microalgae. Considering the recent isolation of microplastics from freshwater samples by FCM (Sgier et al., 2016) as well as technical advances in staining of non-fluorescent microplastic particles for detection and quantification purposes (Maes et al., 2017; Shim et al., 2016), flow cytometry represents a promising tool for efficiently detecting, quantifying and even isolating (when coupled to a sorter (Sgier et al., 2016)) the fraction of small microplastics $(<200 \mu \mathrm{m})$ that remain largely unknown in marine environments (Huvet et al., 2016). In addition, the use of dynamic imaging particle analysis by FlowCam, which automatically captures digital images of particles as they are carried in a fluid stream and thus combines the quantitative power of flow cytometry with microscopy tools, could lead to great advances in the field of microplastic research.

\section{Conclusion}

The interactions and impacts of $2 \mu \mathrm{m}$ micro-PS $\left(3.96 \mu \mathrm{g} \mathrm{L}^{-1}\right)$ on marine phytoplankton was experimentally assessed on 3 microalgal species using flow cytometry. While no effects of micro-PS exposure was observed on algal growth and fluorescence, distribution of micro-PS in algal cultures appeared dependent on the species and the physiological state of the algae. Hetero-aggregation was exclusively observed with the diatom $C$. neogracile in stationary phase, probably in relation with increase in cell stickiness, EPS production and/or bacterial aggregates that changed with the age of the culture. This study also provided some methodological recommendations to properly assess the 
particle distribution and bioavailability when conducting microplastics laboratory experiments. Finally, the present work highlighted the use of flow cytometry as a promising tool to quantify and characterize small microplastics $(<200 \mu \mathrm{m})$ in seawater.

\section{Acknowledgments}

This work was carried out as part of the MICRO project (EU INTERREG IVA - Seas (MICRO 09-002$\mathrm{BE}$ ), the ANR CESA project (ANR-15-CE34-0006-02, NANOPLASTICS project) and the MICROPLASTIC2 project supported by the Single Interministerial Fund (FUI) and local communities (CR Bretagne, CR PACA, CD29, CATPM and Brest Métropole). The authors thank Valentin Foulon for the microscope pictures, Prof. Dianne Jolley, Darren Koppel and Helen McCombie for the English corrections.

\section{References list}

Alldredge, A.L., Passow, U., Logan, B.E., 1993. The abundance and significance of a class of large, transparent organic particles in the ocean. Deep. Res. Part I 40, 1131-1140. doi:10.1016/09670637(93)90129-Q

Arthur, C., Baker, J., Bamford, H., 2009. Proceedings of the International Research Workshop on the Occurrence, Effects and Fate of Microplastic Marine Debris. September 9-11, 2008. NOAA Technical Memorandum NOS-OR\&R-30.

Barnes, D.K., Galgani, F., Thompson, R.C., Barlaz, M., 2009. Accumulation and fragmentation of plastic debris in global environments. Philos. Trans. R. Soc. Lond. B. Biol. Sci. 364, 1985-1998. doi:10.1098/rstb.2008.0205

Bendif, E.M., Probert, I., Schroeder, D.C., de Vargas, C., 2013. On the description of Tisochrysis lutea gen. nov. sp. nov. and Isochrysis nuda sp. nov. in the Isochrysidales, and the transfer of Dicrateria to the Prymnesiales (Haptophyta). J. Appl. Phycol. 25, 1763-1776. doi:10.1007/s10811-013-0037-0

Besseling, E., Foekema, E.M., Van Franeker, J.A., Leopold, M.F., Kühn, S., Bravo Rebolledo, E.L., Heße, E., Mielke, L., IJzer, J., Kamminga, P., Koelmans, A.A., 2015. Microplastic in a macro filter feeder: Humpback whale Megaptera novaeangliae. Mar. Poll. Bull. 95, 248-252. doi:10.1016/j.marpolbul.2015.04.007

Besseling, E., Wang, B., Lürling, M., Koelmans, A.A., 2014. Nanoplastic affects growth of S. obliquus and reproduction of D. magna. Environ. Sci. Technol. 48, 12336-12343. doi:10.1021/es503001d

Bhaskar, P. V., Grossart, H.P., Bhosle, N.B., Simon, M., 2005. Production of macroaggregates from dissolved exopolymeric substances (EPS) of bacterial and diatom origin. FEMS Microbiol. Ecol. 53, 255-264. doi:10.1016/j.femsec.2004.12.013

Bhattacharya, P., Lin, S., Turner, J.P., Ke, P.C., 2010. Physical adsorption of charged plastic nanoparticles affects algal photosynthesis. J. Phys. Chem. C 114, 16556-16561. doi:10.1021/jp1054759

Boerger, C.M., Lattin, G.L., Moore, S.L., Moore, C.J., 2010. Plastic ingestion by planktivorous fishes in the North Pacific Central Gyre. Mar. Poll. Bull. 60, 2275-2278. doi:10.1016/j.marpolbul.2010.08.007 
Browne, M.A., Galloway, T.S., Thompson, R.C., 2010. Spatial patterns of plastic debris along estuarine shorelines. Environ. Sci. Technol. 44, 3404-3409. doi:10.1021/es903784e

Cole, M., Lindeque, P.K., Fileman, E., Halsband, C., Goodhead, R., Moger, J., Galloway, T.S., 2013. Microplastic Ingestion by Zooplankton. Environ. Sci. Technol. 47, 6646-6655. doi:10.1021/es400663f

Cole, M., Lindeque, P., Halsband, C., Galloway, T.S., 2011. Microplastics as contaminants in the marine environment: A review. Mar. Poll. Bull. 62, 2588-2597. doi:10.1016/j.marpolbul.2011.09.025

Cole, M., Lindeque, P.K., Fileman, E., Clark, J., Lewis, C., Halsband, C., Galloway, T.S., 2016. Microplastics Alter the Properties and Sinking Rates of Zooplankton Faecal Pellets. Environ. Sci. Technol. 50, 3239-3246. doi:10.1021/acs.est.5b05905

Dalsgaard, J., John, M. St., Kattner, G., Müller-Navarra, D., Hagen, W., 2003. Fatty acid trophic markers in the pelagic marine environment. In: Southward, A.J., Tyler, P.A., Young, C.M., Fuiman, L.A. (Eds.), Advances in Marine Biology. Elsevier, 227-318. doi:10.1017/CBO9781107415324.004

Davarpanah, E., Guilhermino, L., 2015. Single and combined effects of microplastics and copper on the population growth of the marine microalgae Tetraselmis chuii. Estuar. Coast. Shelf. Sci. 167, 269-275. doi:10.1016/j.ecss.2015.07.023

Dodge, J.D., Crawford, R.M., 1970. A survey of thecal fine structure in the Dinophyceae. Bot. J. Linn. Soc. 63, 53-67. doi:10.1111/j.1095-8339.1970.tb02302.x

Eriksen, M., Lebreton, L.C.M., Carson, H.S., Thiel, M., Moore, C.J., Borerro, J.C., Galgani, F., Ryan, P.G., Reisser, J., 2014. Plastic pollution in the world's oceans: more than 5 trillion plastic pieces weighing over 250,000 tons afloat at sea. PLoS One 9, 1-15. doi:10.1371/journal.pone.0111913

Estrada, M., Henriksen, P., Gasol, J.M., Casamayor, E.O., Pedrós-Alió, C., 2004. Diversity of planktonic photoautotrophic microorganisms along a salinity gradient as depicted by microscopy, flow cytometry, pigment analysis and DNA-based methods. FEMS Microbiol. Ecol. 49, 281-293. doi:10.1016/j.femsec.2004.04.002

Farrell, P., Nelson, K., 2013. Trophic level transfer of microplastic: Mytilus edulis (L.) to Carcinus maenas (L.). Environ. Poll. 177, 1-3. doi:10.1016/j.envpol.2013.01.046

Galbraith, D.W., Harkins, K.R., Jefferson, R.A., 1988. Flow cytometric characterization of the chlorophyll contents and size distributions of plant protoplasts. Cytometry 9, 75-83. doi:10.1002/cyto.990090112

Green, D.S., 2016. Effects of microplastics on European flat oysters, Ostrea edulis and their associated benthic communities. Environ. Poll. 216, 95-103. doi:10.1016/j.envpol.2016.05.043

Guillard, R.R.L., 1975. Culture of phytoplankton for feeding marine invertebrates. In: Culture of Marine Invertebrate Animals. Springer, pp. 29-60.

Hariskos, I., Rubner, T., Posten, C., 2015. Investigation of cell growth and chlorophyll a content of the coccolithophorid alga Emiliania huxleyi by using simple bench-top flow cytometry. J. Bioprocess. Biotech. 5, 2. doi:10.4172/2155-9821.1000234

Hecky, R.E., Mopper, K., Kilham, P., Degens, E.T., 1973. Amino-Acid and Sugar Composition of Diatom Cell-Walls. Mar. Biol. 19, 323-331.

Hidalgo-ruz, V., Gutow, L., Thompson, R.C., Thiel, M., 2012. Microplastics in the Marine Environment: A Review of the Methods Used for Identification and Quantification. Environ. Sci. Technol. 46, 3060-3075. doi:dx.doi.org/10.1021/es2031505

Huvet, A., Paul-Pont, I., Fabioux, C., Lambert, C., Suquet, M., Thomas, Y., 2016. Quantifying the smallest microplastics is the challenge for a comprehensive view of their environmental impacts. Proc. Natl. Acad. Sci. 124-126. doi:10.1073/pnas.1607221113

Jambeck, J.R., Geyer, R., Wilcox, C., Siegler, T.R., Perryman, M., Andrady, A., Narayan, R., Law, K.L., 2015. Plastic waste inputs from land into the ocean. Science 347, 768-771. doi:10.1126/science.1260352 
Jemec, A., Horvat, P., Kunej, U., Bele, M., Kržan, A., 2016. Uptake and effects of microplastic textile fibers on freshwater crustacean Daphnia magna. Environ. Poll. 219, 201-209. doi:10.1016/j.envpol.2016.10.037

Joiris, C., Billen, G., Lancelot, C., Daro, M.H., Mommaerts, J.P., Bertels, A., Bossicart, M., Nijs, J., Hecq, J.H., 1982. A budget of carbon cycling in the Belgian coastal zone: relative roles of zooplankton, bacterioplankton and benthos in the utilization of primary production. Netherlands J. Sea Res. 16, 260-275. doi:10.1016/0077-7579(82)90035-7

Kiørboe, T., Andersen, K.P., Dam, H.G., 1990. Coagulation efficiency and aggregate formation in marine phytoplankton. Mar. Biol. 107, 235-245. doi:10.1007/BF01319822

Kiørboe, T., Hansen, J.L. S, 1993. Phytoplankton aggregate formation: Observations of patterns and mechanisms of cell sticking and the significance of exopolymeric material. J. Plankton Res. 15, 993-1018. doi:10.1093/plankt/15.9.993

Lagarde, F., Olivier, O., Zanella, M., Daniel, P., Hiard, S., Caruso, A., 2016. Microplastic interactions with freshwater microalgae: Hetero-aggregation and changes in plastic density appear strongly dependent on polymer type. Environ. Poll. 215, 331-339. doi:10.1016/j.envpol.2016.05.006

Legrand, C., Granéli, E., Carlsson, P., 1998. Induced phagotrophy in the photosynthetic dinoflagellate Heterocapsa triquetra. Aquat. Microb. Ecol. 15, 65-75.

Lelong, A., Haberkorn, H., Le Goïc, N., Hégaret, H., Soudant, P., 2011a. A new insight into allelopathic effects of Alexandrium minutum on photosynthesis and respiration of the diatom Chaetoceros neogracile revealed by photosynthetic-performance analysis and flow cytometry. Microb. Ecol. 62, 919-930. doi:10.1007/s00248-011-9889-5

Lelong, A., Hégaret, H., Soudant, P., 2011b. Cell-based measurements to assess physiological status of Pseudo-nitzschia multiseries, a toxic diatom. Res. Microbiol. 162, 970-981. doi:10.1016/j.resmic.2011.06.005

Lenz, R., Enders, K., Gissel, T., 2016. Microplastic exposure studies should be environmentally realistic. Proc. Natl. Acad. Sci. 113, 2-3. doi:10.1073/pnas.1606615113

Li, S., Winters, H., Jeong, S., Emwas, A.H., Vigneswaran, S., Amy, G.L., 2016. Marine bacterial transparent exopolymer particles (TEP) and TEP precursors: Characterization and RO fouling potential. Desalination 379, 68-74. doi:10.1016/j.desal.2015.10.005

Logan, B.E., Alldredge, A.L., 1989. Potential for increased nutrient uptake by flocculating diatoms. Mar. Biol. 101, 443-450. doi:10.1007/BF00541645

Long, M., Moriceau, B., Gallinari, M., Lambert, C., Huvet, A., Raffray, J., Soudant, P., 2015. Interactions between microplastics and phytoplankton aggregates: Impact on their respective fates. Mar. Chem. 175, 39-46. doi: 10.1016/j.marchem.2015.04.003

Lusher, A.L., McHugh, M., Thompson, R.C., 2013. Occurrence of microplastics in the gastrointestinal tract of pelagic and demersal fish from the English Channel. Mar. Poll. Bull. 67, 94-99. doi:10.1016/j.marpolbul.2012.11.028

Maes, T., Jessop, R., Wellner, N., Haupt, K., Mayes, A.G., 2017. A rapid-screening approach to detect and quantify microplastics based on fluorescent tagging with Nile Red. Sci. Rep. 7, 44501. doi:10.1038/srep44501

Malviya, S., Scalco, E., Audic, S., Vincent, F., Veluchamy, A., Poulain, J., Wincker, P., ludicone, D., de Vargas, C., Bittner, L., Zingone, A., Bowler, C., 2016. Insights into global diatom distribution and diversity in the world's ocean. Proc. Natl. Acad. Sci. 113, E1516-E1525. doi:10.1073/pnas.1509523113

Marie, D., Brussaard, C.P.D., Thyrhaug, R., Bratbak, G., Vaulot, D., 1999. Enumeration of marine viruses in culture and natural samples by flow cytometry. Appl. Environ. Microbiol. 65, 45-52.

Murray, F., Cowie, P.R., 2011. Plastic contamination in the decapod crustacean Nephrops norvegicus (Linnaeus, 1758). Mar. Pollut. Bull. 62, 1207-1217. doi:10.1016/j.marpolbul.2011.03.032

Passow, U., 2002a. Transparent Exopolymer Particles in Aquatic Environments. Prog. Oceanogr. 55, 287-333. doi:10.1016/S0079-6611(02)00138-6

Passow, U., 2002b. Production of transparent exopolymer particles (TEP) by phyto- and bacterioplankton. Mar. Ecol. Prog. Ser. 236, 1-12. doi:10.3354/meps236001 
Passow, U., Alldredge, A.L., Logan, B.E., 1994. The role of particulate carbohydrate exudates in the flocculation of diatom blooms. Deep Res. Part I 41, 335-357. doi:10.1016/09670637(94)90007-8

Paul-Pont, I., Lacroix, C., González Fernández, C., Hégaret, H., Lambert, C., Le Goïc, N., Frère, L., Cassone, A.L., Sussarellu, R., Fabioux, C., Guyomarch, J., Albentosa, M., Huvet, A., Soudant, P., 2016. Exposure of marine mussels Mytilus spp. to polystyrene microplastics: Toxicity and influence on fluoranthene bioaccumulation. Environ. Poll. 216, 724-737. doi:10.1016/j.envpol.2016.06.039

Pomati, F., Jokela, J., Simona, M., Veronesi, M., Ibelings, B.W., 2011. An automated platform for phytoplankton ecology and aquatic ecosystem monitoring. Environ. Sci. Technol. 45, 96589665. doi:10.1021/es201934n

R Foundation for Statistical Computing, Vienna, A.I. 3-900051-07-0, 2011. R Development Core Team. R A Lang. Environ. Stat. Comput. 55, 275-286.

Reisser, J., Shaw, J., Hallegraeff, G., Proietti, M., Barnes, D.K.A., Thums, M., Wilcox, C., Hardesty, B.D., Pattiaratchi, C., 2014. Millimeter-sized marine plastics: A new pelagic habitat for microorganisms and invertebrates. PLoS One 9, 1-11. doi:10.1371/journal.pone.0100289

Robert, R., Chretiennot-Dinet, M.-J., Kaas, R., Martin-jezequel, V., Moal, J., Le Coz, J., Nicolas, J., Bernard, E., Connan, J., Le Dean, L., Le Gourrierec, G., Leroy, B., Quere, C., 2004. Amélioration des productions phytoplanctoniques en écloserie de mollusques: caractérisation des microalgues fourrage. Rapport Ifremer, DRV/RA/RST/LPI/2004-05

Rochman, C.M., Browne, M.A., Underwood, A.J., Van Franeker, J.A., Thompson, R.C., Amaral-Zettler, L.A., 2016. The ecological impacts of marine debris: Unraveling the demonstrated evidence from what is perceived. Ecology 97, 302-312. doi:10.1890/14-2070.1

Rossi, G., Monticelli, L., 2014. Modeling the effect of nano-sized polymer particles on the properties of lipid membranes. J. Phys. Condens. Matter 26, 503101. doi:10.1088/09538984/26/50/503101

Rummel, C.D., Löder, M.G.J., Fricke, N.F., Lang, T., Griebeler, E.M., Janke, M., Gerdts, G., 2016. Plastic ingestion by pelagic and demersal fish from the North Sea and Baltic Sea. Mar. Poll. Bull. 102, 134-141. doi:10.1016/j.marpolbul.2015.11.043

Sanchez, W., Bender, C., Porcher, J.M., 2014. Wild gudgeons (Gobio gobio) from French rivers are contaminated by microplastics: Preliminary study and first evidence. Environ. Res. 128, 98100. doi:10.1016/j.envres.2013.11.004

Setälä, O., Fleming-Lehtinen, V., Lehtiniemi, M., 2014. Ingestion and transfer of microplastics in the planktonic food web. Environ. Poll. 185, 77-83. doi:10.1016/j.envpol.2013.10.013

Sgier, L., Freimann, R., Zupanic, A., Kroll, A., 2016. Flow cytometry combined with viSNE for the analysis of microbial biofilms and detection of microplastics. Nat. Commun. 7, 11587. doi:10.1038/ncomms11587

Shim, W.J., Song, Y.K., Hong, S.H., Jang, M., 2016. Identification and quantification of microplastics using Nile Red staining. Mar. Poll. Bull. 113, 469-476. doi:10.1016/j.marpolbul.2016.10.049

Sjollema, S.B., Redondo-Hasselerharm, P., Leslie, H.A., Kraak, M.H.S., Vethaak, A.D., 2016. Do plastic particles affect microalgal photosynthesis and growth? Aquat. Toxicol. 170, 259-261. doi:10.1016/j.aquatox.2015.12.002

Sosik, H.M., Chisholm, S.W., Olson, R.J., 1989. Chlorophyll fluorescence from single cells: Interpretation of flow cytometric signals. Limnol. Oceanogr. 34, 1749-1761. doi:10.4319/lo.1989.34.8.1749

Sussarellu, R., Suquet, M., Thomas, Y., Lambert, C., Fabioux, C., Pernet, M.E.J., Le Goïc, N., Quillien, V., Mingant, C., Epelboin, Y., Corporeau, C., Guyomarch, J., Robbens, J., Paul-Pont, I., Soudant, P., Huvet, A., 2016. Oyster reproduction is affected by exposure to polystyrene microplastics. Proc. Natl. Acad. Sci. 113, 2430-2435. doi:10.1073/pnas.1519019113

Tosetto, L., Williamson, J.E., Brown, C., 2017. Trophic transfer of microplastics does not affect fish personality. Anim. Behav. 123, 159-167. doi:10.1016/j.anbehav.2016.10.035 
Van Cauwenberghe, L., Claessens, M., Vandegehuchte, M.B., Janssen, C.R., 2015. Microplastics are taken up by mussels (Mytilus edulis) and lugworms (Arenicola marina) living in natural habitats. Environ. Poll. 199, 10-17. doi:10.1016/j.envpol.2015.01.008

Van Cauwenberghe, L., Janssen, C.R., 2014. Microplastics in bivalves cultured for human consumption. Environ. Poll. 193, 65-70. doi:10.1016/j.envpol.2014.06.010

Van Sebille, E., Wilcox, C., Lebreton, L., Maximenko, N., Hardesty, B.D., van Franeker, J.A., Eriksen, M., Siegel, D., Galgani, F., Law, K.L., 2015. A global inventory of small floating plastic debris. Environ. Res. Lett. 10, 124006. doi:10.1088/1748-9326/10/12/124006

Von Moos, N., Burkhardt-Holm, P., Köhler, A., 2012. Uptake and effects of microplastics on cells and tissue of the blue mussel Mytilus edulis L. after an experimental exposure. Environ. Sci. Technol. 46, 11327-11335. doi:10.1021/es302332w

Ward, J.E., Kach, D.J., 2009. Marine aggregates facilitate ingestion of nanoparticles by suspensionfeeding bivalves. Mar. Environ. Res. 68, 137-142. doi:10.1016/j.marenvres.2009.05.002

Woodall, L.C., Sanchez-Vidal, A., Canals, M., Paterson, G.L.J., Coppock, R., Sleight, V., Calafat, A., Rogers, A.D., Narayanaswamy, B.E., Thompson, R.C., 2014. The deep sea is a major sink for microplastic debris. R. Soc. Open Sci. 1, 140317. doi:10.1098/rsos.140317

Wright, S.L., Thompson, R.C., Galloway, T.S., 2013. The physical impacts of microplastics on marine organisms: A review. Environ. Poll. 178, 483-492. doi:10.1016/j.envpol.2013.02.031

Zettler, E.R., Mincer, T.J., Amaral-Zettler, L.A., 2013. Life in the "Plastisphere": microbial communities on plastic marine debris. Environ. Sci. Technol. 47, 7137.

Zhang, C., Chen, X., Wang, J., Tan, L., 2017. Toxic effects of microplastic on marine microalgae Skeletonema costatum: Interactions between microplastic and algae. Environ. Poll. 220, 12821288. doi:10.1016/j.envpol.2016.11.005 
Figure 1. Cytograms of Chaetoceros neogracile culture (A, B and C), micro-PS solution (D, E and F) and C. neogracile culture exposed to micro-PS (G, H and I). The total microalgal population is illustrated on $\operatorname{dot}$ plots $A, D$ and $G$, representing red fluorescence (Fl3-Height) vs. forward scatter (FSC-Height). Free C. neogracile cells (purple blue region), residual free micro-PS (green region) and $C$. neogracile/micro-PS hetero-aggregates (orange region) can be distinguished on dot plots $\mathrm{B}, \mathrm{E}$ and $\mathrm{H}$, representing red fluorescence (FI3-Height) vs. green fluorescence (FL1-Height). Free algal cells (purple line) and hetero-aggregates (orange line) can also be distinguished on histograms C, F and I, representing the counts vs. green fluorescence (Fl1-Height). The entire free micro-PS population was visible and quantified with other flow cytometry settings (data not shown).

Figure 2. Microplastic partitioning over a growth cycle expressed as the percentage of total micro-PS. A: Control flask, B: Chaetoceros neogracile, C: Heterocapsa triquetra, D: Tisochrysis lutea. Solid green lines represent the microalgal concentration (cells $\mathrm{mL}^{-1}$ ); dot-dashed yellow lines represent the percentage of free suspended micro-PS; dotted blue lines represent the percentage of micro-PS adsorbed to the glassware and long dash red lines the percentage of hetero-aggregates. Error bars represent the standard error $(n=3)$.

Figure 3. A: Micrograph of a bacterial aggregate after Sybr Green staining (1X final concentration); bacteria can be seen in green (without micro-PS). B: Micrograph of micro-PS (green) free and trapped in bacterial aggregate (not SybrGreen stained). Both microbial aggregates and micro-PS are visible in green. C: Micrograph of micro-PS and Chaetoceros neogracile as free particles and heteroaggregates, arrows indicate micro-PS. D: Orthogonal view from 3-Dimensional micrograph $(x 40)$ of a H. triquetra cell that has phagocytosed micro-PS. Phagocytosed micro-PS (in green) trapped between chloroplasts (in red). The central picture shows a reconstruction of 16 stacked fluorescence images (thickness $=7.5 \mu \mathrm{m}$ ). The flanking pictures show cross-sections compiled along the z-axis (left box) and $x$-axis (upper box). For 3D visualisation, please see the supplementary files. E: Micrograph of lysed cell of $H$. triquetra with micro-PS (green) trapped in lysis products. F: Maximum intensity projection of a $H$. triquetra/micro-PS heteroaggregate stained with calcofluor ( $1 \%$ final concentration). A H. triquetra cell is visible in blue under Dapi filters (Excitation 406/15nm, Emission 457/50 nm). Bacterial nuclei (picture A) and micro-PS (pictures B, D, E and F) are visible in green under GFP filters (Excitation 494/20nm, Emission 536/40 nm). Chlorophyll (pictures D and E) is visible in red under DsRed filters (Excitation 575/25nm, Emission 628/40 nm). 
Figure 1
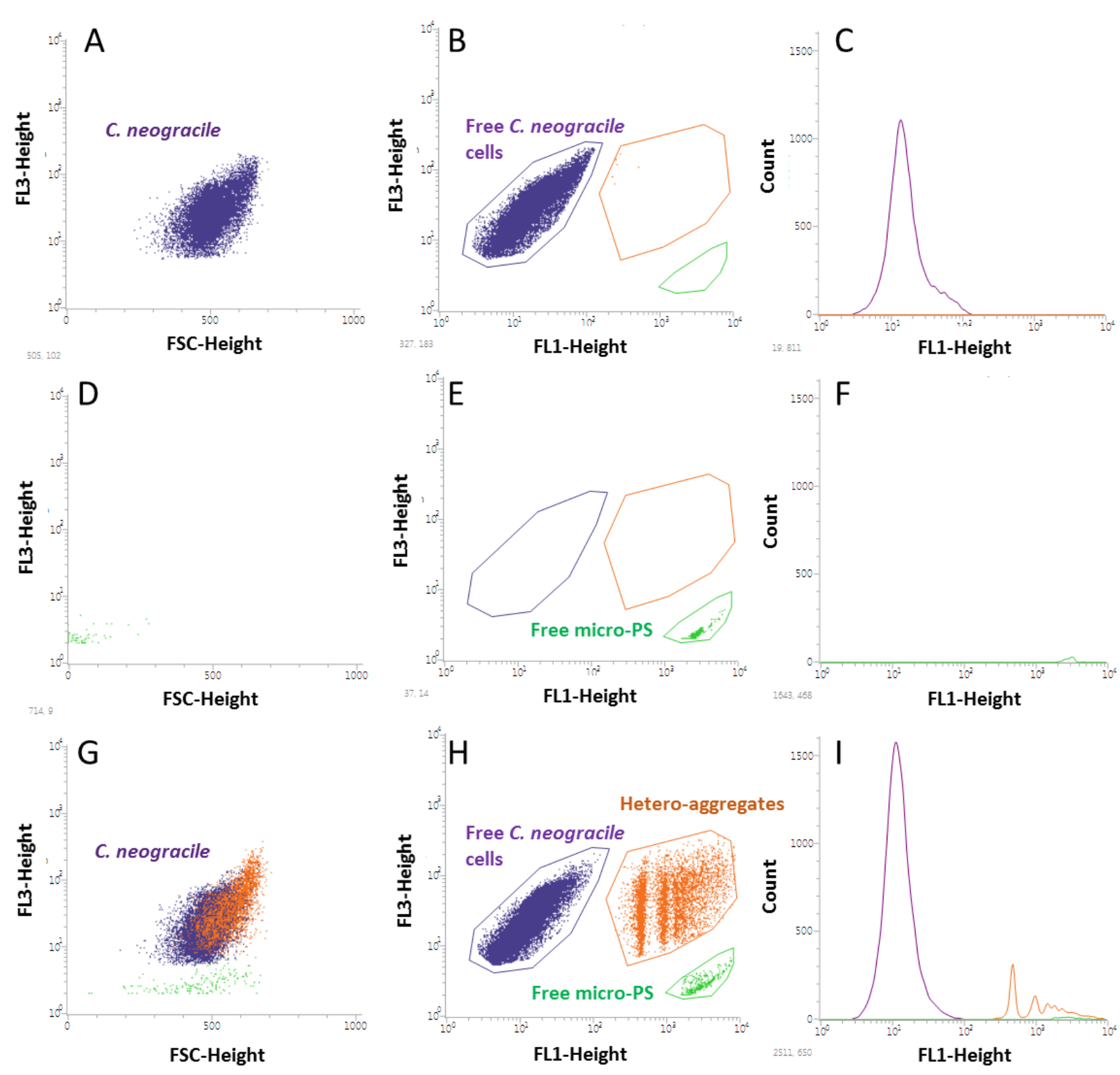
Figure 2
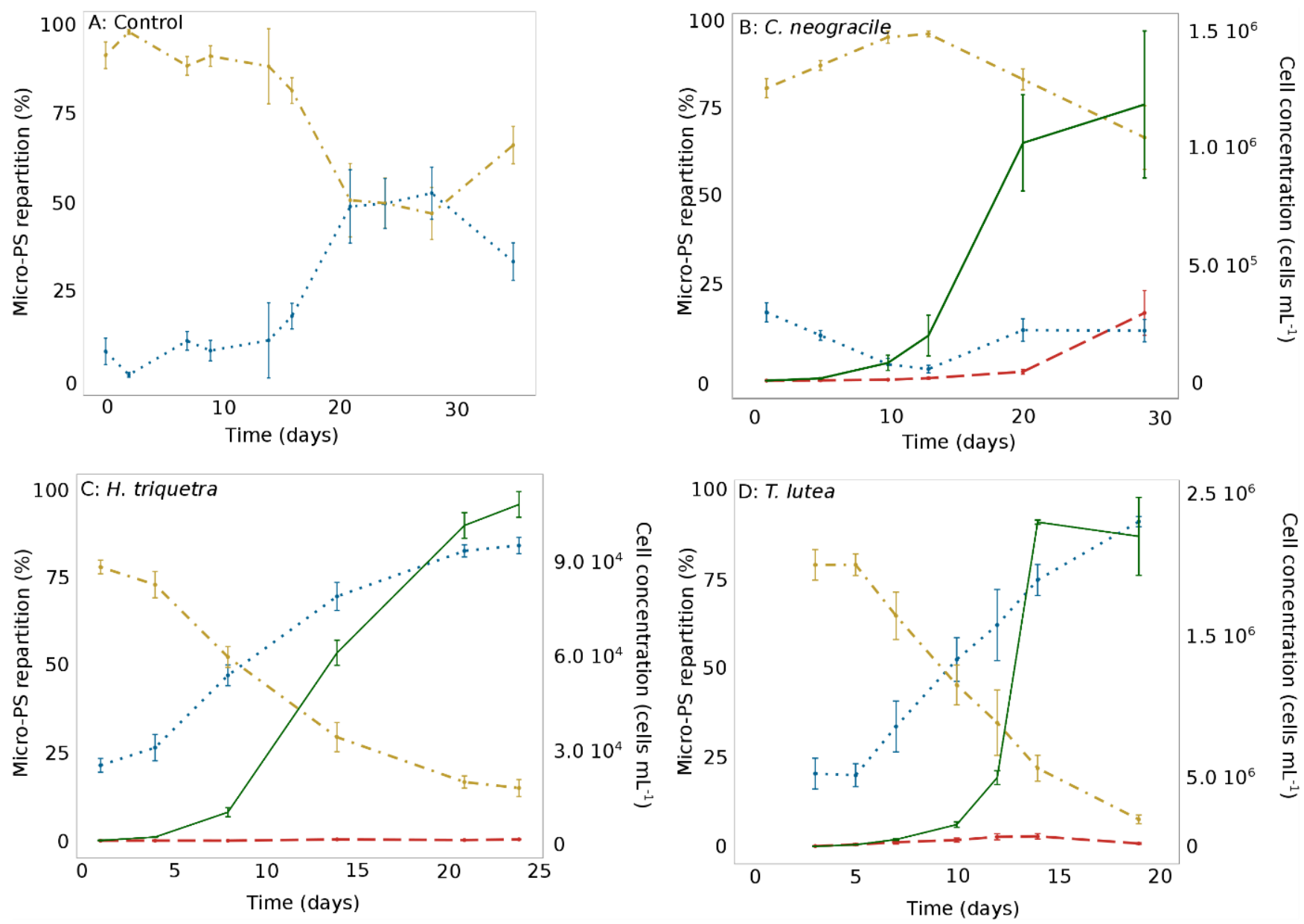
Figure 3
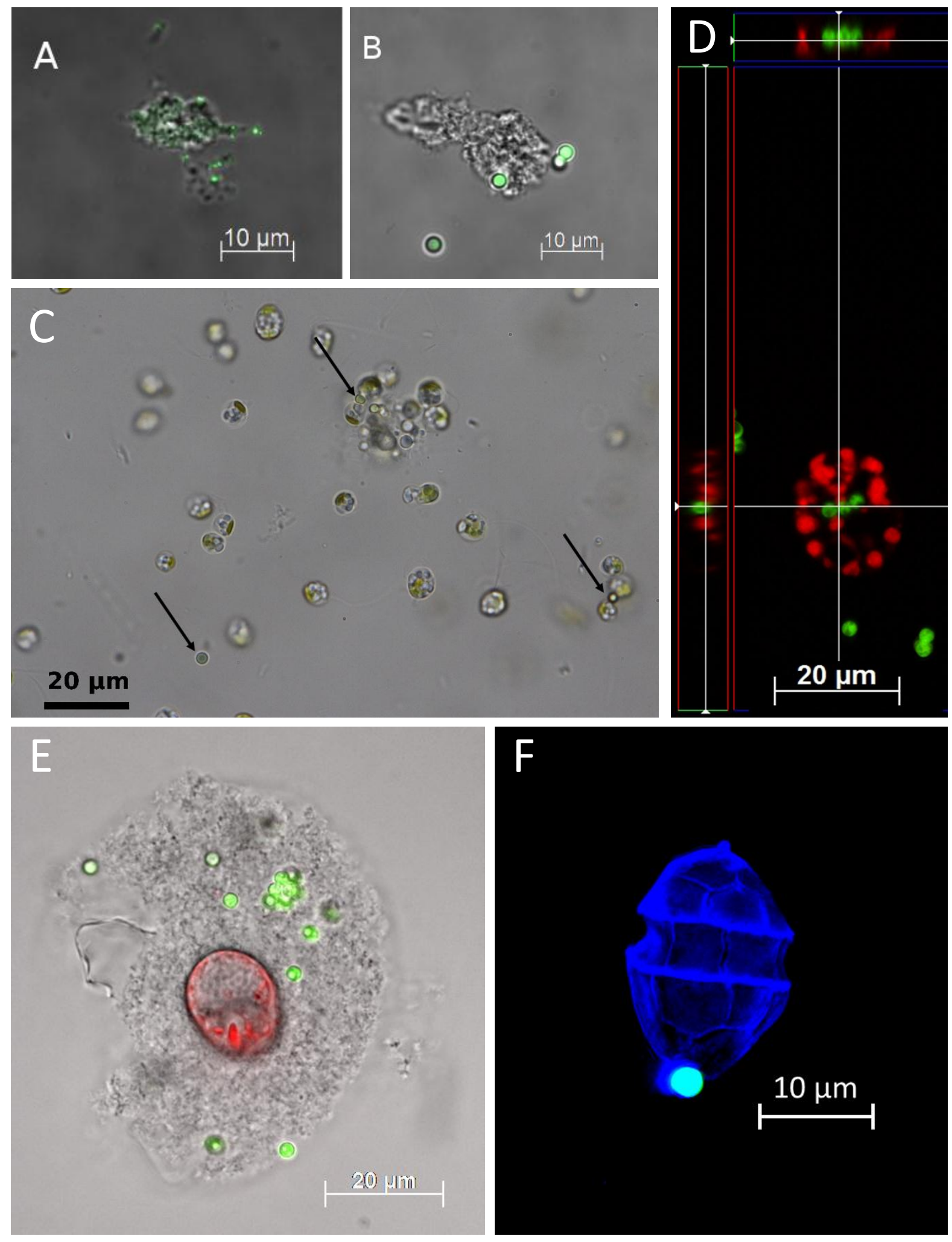


\title{
Interactions between polystyrene microplastics and marine phytoplankton lead to species-specific hetero-aggregation
}

\author{
Marc Long ${ }^{1}$, Ika Paul-Pont ${ }^{1}$, Hélène Hégaret ${ }^{1}$, Brivaela Moriceau ${ }^{1}$, Christophe Lambert ${ }^{1}$, Arnaud Huvet ${ }^{1}$, \\ Philippe Soudant ${ }^{1}$ \\ ${ }^{1}$ Laboratoire des Sciences de l'Environnement Marin (LEMAR), UMR 6539 CNRS UBO IRD IFREMER - \\ Institut Universitaire Européen de la Mer, Technopôle Brest-Iroise - Rue Dumont d'Urville, 29280 \\ Plouzané, France.
}

*Corresponding author: Marc Long, marc.florian.long@gmail.com

Present/permanent address : LEMAR UMR6539, IUEM Technopôle Brest-Iroise - rue Dumont d'Urville 29280 Plouzané- France.

\section{Supplementary files}

Supplementary table 1: Microplastic partitioning over a growth cycle in C. neogracile cultures for the two micro-PS concentrations tested (90000 micro-PS $\mathrm{mL}^{-1}$ and 900000 micro-PS $\mathrm{mL}^{-1}$ ). Partitioning of total micro-PS is expressed as percentage as free suspended micro-PS (free micro-PS), percentage of hetero-aggregates and percentage of micro-PS adsorbed to the glassware (Flask walls). Results are expressed as mean \pm standard error $(n=3)$. 3

Supplementary table 2: Microplastic partitioning over a growth cycle in $\mathrm{H}$. triquetra cultures for the two micro-PS concentrations tested (90000 micro-PS $\mathrm{mL}^{-1}$ and 900000 micro-PS $\mathrm{mL}^{-1}$ ). Partitioning of total micro-PS is expressed as percentage as free suspended micro-PS (free micro-PS), percentage of heteroaggregates and percentage of micro-PS adsorbed to the glassware (Flask walls). Results are expressed as mean \pm standard error $(n=3)$.

Supplementary table 3: Microplastic partitioning over a growth cycle in $T$. lutea cultures for the two micro-PS concentrations tested (90000 micro-PS $\mathrm{mL}^{-1}$ and 900000 micro-PS $\mathrm{mL}^{-1}$ ). Partitioning of total micro-PS is expressed as percentage as free suspended micro-PS (free micro-PS), percentage of heteroaggregates and percentage of micro-PS adsorbed to the glassware (Flask walls). Results are expressed as mean \pm standard error $(n=3)$. 3

Supplementary table 4: Mean forward scatter (FSC; arbitrary units) of microalgal cells during the growth cycle for the control and microalgae exposed to high micro-PS concentration (900 000 micro-PS $\mathrm{mL}^{-1}$ ). Initial, mid-exponential and stationary phases were measured at days 1, 13 and 22 for Chaetoceros neogracile; days 3, 7 and 19 for Tisochrisis lutea; and days 1, 14 and 24 for Heterocapsa triquetra, respectively. Values are expressed as the mean \pm standard error $(n=3)$. 
Supplementary table 5: Mean side scatter (SSC; arbitrary units) of microalgal cells during growth cycle for the control and microalgae exposed to high micro-PS concentration (900 000 micro-PS $\mathrm{mL}^{-1}$ ). Initial, mid exponential and stationary phases were measured at days 1, 13 and 22 for Chaetoceros neogracile; at days 3, 7 and 19 for Tisochrisis lutea; and days 1, 14 and 24 for Heterocapsa triquetra, respectively. Values are expressed as the mean \pm standard error $(n=3)$.

Supplementary table 6: Mean relative chlorophyll fluorescence intensity (FL3; arbitrary units) of microalgal cells during the growth cycle for for the control and microalgae exposed to the high micro-PS concentration (900 000 micro-PS $\mathrm{mL}^{-1}$ ). Initial, mid-exponential and stationary phases were measured at days 1, 13 and 22 for Chaetoceros neogracile; at day 3, 7, 19 for Tisochrisis lutea; and days 1, 14 and 24 for Heterocapsa triquetra, respectively. Values are expressed as the mean \pm standard error $(n=3)$. 5

Supplementary table 7: Mean growth rates during exponential growth phase for the controls, the cultures exposed to 90000 micro-PS $\mathrm{mL}^{-1}$ and 900000 micro-PS $\mathrm{mL}^{-1}$. Values are expressed as the mean \pm standard error $(n=3)$. 
Supplementary table 1:

\begin{tabular}{|c|c|c|c|c|c|c|}
\hline \multicolumn{7}{|c|}{ C. neogracile } \\
\hline \multicolumn{4}{|c|}{90000 micro-PS mL $^{-1}$} & \multicolumn{3}{|c|}{900000 micro-PS mL ${ }^{-1}$} \\
\hline Days & $\begin{array}{c}\text { Free } \\
\text { micro-PS }\end{array}$ & $\begin{array}{l}\text { Hetero- } \\
\text { aggregates }\end{array}$ & Flask walls & $\begin{array}{c}\text { Free } \\
\text { micro-PS }\end{array}$ & $\begin{array}{l}\text { Hetero- } \\
\text { aggregates }\end{array}$ & Flask walls \\
\hline 1 & $81.0 \pm 2.7$ & $0.0 \pm 0.0$ & $18.9 \pm 2.6$ & $84.5 \pm 3.1$ & $0.0 \pm 0.0$ & $15.5 \pm 3.1$ \\
\hline 5 & $87.4 \pm 1.3$ & $0.1 \pm 0.3$ & $12.5 \pm 1.3$ & $90.2 \pm 1.9$ & $0.1 \pm 0.0$ & $9.7 \pm 1.9$ \\
\hline 10 & $95.2 \pm 1.7$ & $0.3 \pm 0.1$ & $4.5 \pm 1.7$ & $96.9 \pm 2.0$ & $0.3 \pm 0.1$ & $2.8 \pm 2.0$ \\
\hline 13 & $96.1 \pm 0.8$ & $0.7 \pm 0.3$ & $3.2 \pm 1.1$ & $97.1 \pm 1.8$ & $0.7 \pm 0.2$ & $2.2 \pm 1.9$ \\
\hline 20 & $83.5 \pm 2.9$ & $2.5 \pm 0.7$ & $14.0 \pm 3.1$ & $88.0 \pm 2.0$ & $2.5 \pm 0.3$ & $9.5 \pm 2.3$ \\
\hline 29 & $67.4 \pm 8.8$ & $18.8 \pm 6.2$ & $13.9 \pm 3.1$ & $75.6 \pm 1.7$ & $7.3 \pm 3.4$ & $17.1 \pm 5.0$ \\
\hline
\end{tabular}

Supplementary table 2:

\begin{tabular}{|c|c|c|c|c|c|c|}
\hline \multicolumn{7}{|c|}{ H. triquetra } \\
\hline \multicolumn{4}{|c|}{90000 micro-PS mL ${ }^{-1}$} & \multicolumn{3}{|c|}{900000 micro-PS mL ${ }^{-1}$} \\
\hline Days & $\begin{array}{c}\text { Free } \\
\text { micro-PS }\end{array}$ & $\begin{array}{l}\text { Hetero- } \\
\text { aggregates }\end{array}$ & Flask walls & $\begin{array}{c}\text { Free } \\
\text { micro-PS }\end{array}$ & $\begin{array}{l}\text { Hetero- } \\
\text { aggregates }\end{array}$ & Flask walls \\
\hline 1 & $78.4 \pm 2.2$ & $0.0 \pm 0.0$ & $22.9 \pm 2.2$ & $53.9 \pm 1.3$ & $0.0 \pm 0.0$ & $46.1 \pm 1.3$ \\
\hline 4 & $73.3 \pm 3.8$ & $0.0 \pm 0.0$ & $26.7 \pm 3.8$ & $48.9 \pm 0.4$ & $0.0 \pm 0.0$ & $51.1 \pm 0.4$ \\
\hline 8 & $52.6 \pm 3.0$ & $0.0 \pm 0.0$ & $47.4 \pm 3.0$ & $39.0 \pm 2.5$ & $0.1 \pm 0.0$ & $61.0 \pm 2.5$ \\
\hline 14 & $29.7 \pm 4.2$ & $0.4 \pm 0.2$ & $70.0 \pm 4.0$ & $22.9 \pm 2.1$ & $0.5 \pm 0.2$ & $76.7 \pm 2.0$ \\
\hline 21 & $16.8 \pm 1.7$ & $0.2 \pm 0.0$ & $83.0 \pm 1.7$ & $14.2 \pm 2.8$ & $0.1 \pm 0.0$ & $85.7 \pm 2.8$ \\
\hline 24 & $15.1 \pm 2.4$ & $0.4 \pm 0.1$ & $84.5 \pm 2.3$ & $15.1 \pm 1.4$ & $0.1 \pm 0.0$ & $84.8 \pm 1.4$ \\
\hline
\end{tabular}

Supplementary table 3:

\begin{tabular}{|c|c|c|c|c|c|c|}
\hline \multicolumn{7}{|c|}{ T. lutea } \\
\hline \multicolumn{4}{|c|}{90000 micro-PS mL ${ }^{-1}$} & \multicolumn{3}{|c|}{ 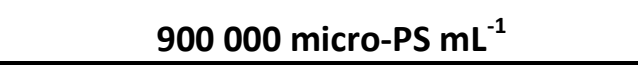 } \\
\hline Days & $\begin{array}{c}\text { Free } \\
\text { micro-PS }\end{array}$ & $\begin{array}{l}\text { Hetero- } \\
\text { aggregates }\end{array}$ & Flask walls & $\begin{array}{c}\text { Free } \\
\text { micro-PS }\end{array}$ & $\begin{array}{l}\text { Hetero- } \\
\text { aggregates }\end{array}$ & Flask walls \\
\hline 3 & $79.1 \pm 4.3$ & $0.3 \pm 0.1$ & $20.6 \pm 4.3$ & $81.9 \pm 0.4$ & $0.1 \pm 0.0$ & $18.0 \pm 0.3$ \\
\hline 5 & $79.2 \pm 3.0$ & $0.7 \pm 0.3$ & $20.1 \pm 3.2$ & $80.9 \pm 1.2$ & $0.4 \pm 0.0$ & $18.7 \pm 1.2$ \\
\hline 7 & $64.9 \pm 6.7$ & $1.3 \pm 0.5$ & $33.8 \pm 7.1$ & $79.4 \pm 3.9$ & $0.6 \pm 0.1$ & $20.0 \pm 3.8$ \\
\hline 10 & $45.5 \pm 5.6$ & $1.9 \pm 0.6$ & $52.6 \pm 6.1$ & $58.7 \pm 1.6$ & $0.9 \pm 0.1$ & $40.4 \pm 1.5$ \\
\hline 12 & $34.9 \pm 9.2$ & $2.9 \pm 0.9$ & $62.3 \pm 10.0$ & $46.5 \pm 2.3$ & $1.5 \pm 0.1$ & $52.0 \pm 2.4$ \\
\hline 14 & $22.1 \pm 3.6$ & $3.0 \pm 0.8$ & $74.9 \pm 4.4$ & $28.9 \pm 3.3$ & $1.2 \pm 0.6$ & $69.9 \pm 3.3$ \\
\hline 19 & $7.7 \pm 1.2$ & $1.0 \pm 0.2$ & $91.3 \pm 1.4$ & $8.5 \pm 2.0$ & $0.7 \pm 0.0$ & $89.9 \pm 2.0$ \\
\hline
\end{tabular}


Supplementary table 4:

\begin{tabular}{|c|c|c|c|c|c|}
\hline Species & Condition & $\begin{array}{c}\text { Exponential } \\
\text { growth phase } \\
\text { duration }\end{array}$ & $\begin{array}{c}\text { FSC } \\
\text { Initial }\end{array}$ & mid-exponential & $\begin{array}{c}\text { FSC } \\
\text { stationary }\end{array}$ \\
\hline \multirow{2}{*}{ C. neogracile } & Control & \multirow{2}{*}{22} & $75.3 \pm 2.9$ & $73.6 \pm 0.8$ & $80.5 \pm 1.1$ \\
\hline & Micro-PS & & $68.9 \pm 1.4$ & $71.3 \pm 0.7$ & $82.1 \pm 0.6$ \\
\hline \multirow{2}{*}{ T. lutea } & Control & \multirow{2}{*}{15} & $62.4 \pm 1.9$ & $43.9 \pm 0.3$ & $30.8 \pm 0.5$ \\
\hline & Micro-PS & & $56.5 \pm 1.85$ & $42.2 \pm 0.1$ & $30.4 \pm 0.4$ \\
\hline \multirow{2}{*}{ H. triquetra } & Control & \multirow{2}{*}{23} & $114.1 \pm 3.8$ & $114.3 \pm 1.2$ & $110.4 \pm 1.1$ \\
\hline & Micro-PS & & $112 \pm 2.4$ & $113.8 \pm 3.6$ & $107.6 \pm 0.9$ \\
\hline
\end{tabular}

Supplementary table 5:

\begin{tabular}{cccccc}
\hline Species & Condition & $\begin{array}{c}\text { Exponential } \\
\text { growth phase } \\
\text { duration }\end{array}$ & Initial & mid-exponential & stationary \\
\hline \multirow{2}{*}{ C. neogracile } & Control & 22 & $13.0 \pm 0.9$ & $7.5 \pm 0.4$ & $6.4 \pm 0.5$ \\
& Micro-PS & & $11.8 \pm 0.9$ & $7.5 \pm 0.3$ & $7.1 \pm 0.3$ \\
& Control & 15 & $14.1 \pm 0.9$ & $7.6 \pm 0.2$ & $4.8 \pm 0.1$ \\
H. lutea & Micro-PS & & $23.6 \pm 9.1$ & $10.1 \pm 0.6$ & $5.1 \pm 0.1$ \\
& Control & 23 & $185.9 \pm 2.2$ & $139.5 \pm 7.8$ & $145.6 \pm 1.8$ \\
& Micro-PS & 23 & $176 \pm 2.2$ & $139.4 \pm 11.0$ & $145.2 \pm 4.6$ \\
\hline
\end{tabular}


Supplementary table 6:

\begin{tabular}{cccccc}
\hline Species & Condition & $\begin{array}{c}\text { Exponential } \\
\text { growth phase } \\
\text { duration }\end{array}$ & Initial & mid-exponential & stationary \\
\hline \multirow{2}{*}{ C. neogracile } & Control & 22 & $17.5 \pm 0.3$ & $14.6 \pm 0.1$ & FL3 \\
& Micro-PS & 22 & $18.4 \pm 0.1$ & $14.5 \pm 0.1$ & $9.3 \pm 3$ \\
\multirow{2}{*}{ T. lutea } & Control & 15 & $7.5 \pm 0.2$ & $10.4 \pm 0.2$ & $4.5 \pm 0.1$ \\
& Micro-PS & & $7.4 \pm 0.2$ & $9.7 \pm 0.1$ & $4.6 \pm 0.1$ \\
H. triquetra & Control & 23 & $12.5 \pm 0.4$ & $17.6 \pm 0.4$ & $13.9 \pm 0.4$ \\
& Micro-PS & 23 & $12.4 \pm 0.1$ & $18.4 \pm 0.4$ & $15.2 \pm 1.4$ \\
\hline
\end{tabular}

Supplementary table 7:

\begin{tabular}{|c|c|c|c|c|}
\hline Species & Condition & $\begin{array}{l}\text { Exponential growth } \\
\text { phase duration }\end{array}$ & 90000 micro-PS mL $^{-1}$ & 900000 micro-PS mL $^{-1}$ \\
\hline \multirow{2}{*}{ C. neogracile } & Control & \multirow{2}{*}{22} & $0.227 \pm 0.004$ & $0.227 \pm 0.004$ \\
\hline & Micro-PS & & $0.227 \pm 0.011$ & $0.235 \pm 0.003$ \\
\hline \multirow{2}{*}{ T. lutea } & Control & \multirow{2}{*}{15} & $0.450 \pm 0.004$ & $0.450 \pm 0.004$ \\
\hline & Micro-PS & & $0.440 \pm 0.005$ & $0.440 \pm 0.005$ \\
\hline \multirow{2}{*}{ H. triquetra } & Control & \multirow{2}{*}{23} & $0.206 \pm 0.006$ & $0.206 \pm 0.006$ \\
\hline & Micro-PS & & $0.198 \pm 0.005$ & $0.195 \pm 0.005$ \\
\hline
\end{tabular}

